Надежда Д. Јовић ${ }^{1}$

Универзитет у Нишу

Филозофски факултет

Департмин за српски језик
УДК 811.163 .41 '271 "1867/1868"

811.163.41'276.6:32“1867/1868“"

DOI: https://doi.org/10.46630/gsrj.17.2019.04

\title{
О ЈЕЗИКУ ЗБОРНИКА ЗАКОНА И УРЕДБА ИЗ 1867. И 1868. ГОДИНЕ
}

\begin{abstract}
У раду су представљене неке језичке особине (графијске, фонетске, морфолошке, творбене и синтаксичке) Зборника закона и уредба из 1867. и 1868. године с циљем да се установе одлике административног стила српског стандарда из времена званичне победе Вукових начела. Поређење је вршено са језичким особинама правних и војних списа из 19. века, са дијалектолошком литературом и са савременим српским стандардом.Установљено је да је у основи језика овог Зборника шумадијско-војвођански дијалекат, а одступања у односу на савремени српски стандард огледају у испуштању сугласника $x$, посебно у облицима заменичко-придевске промене и у широј појави икавизама. Књишки утицај огледа се у непосрбљеној терминологији и у синтакси (употреба некадашњих партиципа у атрибутској функцији, номинализација, ред речи, дуга реченица).
\end{abstract}

Кључне речи: Зборник закона и уредба из 1867. и 1868. године, језичке особине, шумадијско-војвођански дијалекат, српски стандард.

1. Последњих деценија добија на замаху опис језика нижих функционалних стилова (административног, публицистичког, научног) предвуковског периода, као и из времена непосредно пре победе Вукових схватања. ${ }^{3}$ Ово нарочито стога што је то био период њиховог конституисања (МИЛА-

\footnotetext{
${ }^{1}$ nadezda.jovic@filfak.ni.ac.rs

${ }^{2}$ Овај рад рађен је у оквиру пројекта Историја српског језика (178001), који се реализује у сарадњи Филозофског факултета у Новом Саду, Филозофског факултета у Нишу и Филолошко-уметничког факултета у Крагујевцу, под покровитељством Министарства науке, просвете и технолошког развоја Републике Србије. Рад је саопштен на Научном скупу са међународним учешћем Наука и савремени универзитет 2 (Ниш, Филозофски факултет, 16-17. 11. 2012), а за ову прилику је проширен и допуњен новом литературом у сусрет 150-годишњици укидања сваке забране употребе Вукове реформисане графије.

${ }^{3}$ Ирена Грицкат (1964: 130) упозорила је да историја књижевног језика није само језички опис лепе књижевности већ да треба да укључи и проучавање језика других писаних споменика.
} 
НОВИЋ 2004: 113). У жижи интересовања су, пре свега, лексика, терминологија, стил и синтакса. Тиме се свакако попуњава празнина у историји нашег књижевног језика, иако главне језичке особине ових споменика углавном одговарају онима изложеним у Прегледу историје српског језика П. Ивића (1998: 236-244), датим на основу ранијих истраживања језика писаца из истог периода (ЛУКОВИЋ 1994: 137; ЋОРИЋ 2009: 164).

1.1. Административни стил, са правним стилом, као једним од подстилова (ТОШОВИЋ 1988: 81-82), мењао се током XIX века у различитим фазама развитка српске државе (ЛУКОВИЋ 1994: 24). У прве три-четири деценије имао је више рускословенских елемената због великог утицаја учених Срба из Војводине, који су у Србији кнеза Милоша обављали чиновничке дужности (ЛУКОВИЋ 1994: 34). Касније се језик правних аката све више ослобађа ових наноса.

2. Предмет овог рада је језички опис Зборника закона и уредба из 1867. u 1868. године, ${ }^{4}$ њихових кључних графијских, фонетских, морфолошких, творбених и неких синтаксичких особина, с циљем да се на том примеру установе језичке одлике правног стила српског стандарда из времена званичне победе Вукових начела. ${ }^{5}$ Резултати ће бити поређени са језичким особинама војних правила (ЈОВАНОВИЋ 2016: 215-228) и правних уџбеника (ЋОРИЋ 2009: 155-164) из приближно истог периода, ${ }^{6}$ а кад то буде потребно, поредиће се и са стањем у народним говорима, и у стандардном српском језику.

2.1. Зборнищи су невелики по обиму. Први, из 1867. године, има 47 страна, а други, из 1868. године, 64 стране. Штампани су у формату Б5. Садржина закона и уредаба у Зборнику из 1867. различита је и тиче се: устројства судова, регулисања употребе телеграфа, наплате путних такси, пореза, накнаде штете у војним објектима, набавки и поправки у државним болницама и сл. У Зборнику из 1868. године многе уредбе у вези су са убиством кнеза Михаила Обреновића, које се догодило 29. маја те године,

\footnotetext{
${ }^{4}$ Потпуни наслов зборника в. у списку извора на крају рада.

5 Зборник закона и уредба из 1868. године обухваћен је синтаксичко-стилском анализом правних списа у Србији од 1868. до 1918. године М. Луковића (1994).

6 В. Јовановић описивао је језик правила, заправо приручника намењених војним старешинама за различите видове пешадијске обуке регрута, штампаних између 1845. и 1866. године (2016: 216), а Б. Ћорић бавио се језиком два уџбеника права из 1851. године, које је написао Димитрије Матић (2009: 155).

${ }^{7}$ У даљем тексту примери ће бити обележавани двема цифрама, од којих ће прва, 1 или 2, означавати годиште 3борника, старије или млађе, а друга број стране одговарајућег Зборника. Како је Саржај, који долази на почетку, ненумерисан, биће означен скраћеницом $c$ иза прве цифре.
} 
са увођењем ванредног стања и привременог намесништва, као и са „дизањем" ванредног стања и сл.

2.1.1. Законска акта имају своју устаљену форму, стереотипне почетке и завршетке. На почетку је преамбула (Михаил М. Обреновић III, по милости божијој и вољи народа књаз српски, проглашавамо и објављујемо свима и свакоме, да је Државни совет решио и да смо ми одобрили и одобравамо 1.1, 1.2, 1.4, 1.10, 1.27 итд.; Михаил М. Обреновић III, по милости божсјој и вољи народа књаз српски, по договору са Држсавним саветом, решили смо и решавамо 1.3), ${ }^{8}$ а на крају наредба (Препоручујемо нашим министрима... да овај закон обнародују и о извршењу се његовом старају властима пак заповедамо да по юему поступају а свима и свакоме, да му се покоравају 1.1 итд.), испод које следе датум и места за потписе и печат (Видио и ставио државни печат, чувар државног печата, министер правде 1.1 итд.). Језик ових делова текста има више славеносрпских елемената него сам текст уредбе или закона. ${ }^{9}$

2.2. Летимичним увидом у Зборнике стиче се утисак да је реч о књижевном, стандардизованом језику с краја XIX века, чија је основица шумадијско-војвођански дијалекат и који је близак данашњем, али са незнатним уделом дијалектизама у фонетици и морфологији. ${ }^{10}$ Значајнија одступања у односу на савремени српски стандард огледају у испуштању сугласника $x$, посебно у облицима заменичко-придевске промене и у широј појави икавизама. Видно је присутан утицај славеносрпског у фонетици и синтакси (придевске речи долазе иза именице, а некадашњи партиципи у атрибутској функцији чешћи су него данас). У лексици везаној за администрацију, устројство војске и употребу телеграфа приметан је страни утицај (ЈОВИЋ 2011a: 395; JОВАНОВИТ 2016: 223).

3. Зборник из 1867. штампан је славеносрпском ћирилицом и морфофонолошким правописом, као и друге књиге за потребе државних служби

\footnotetext{
${ }^{8}$ Оригинал наведеног транслитерисаног текста изгледа овако: МИХАИЛЪ М. ОБРЕНОВИЋЪ III. по милости божіой и вольи народа КНЯЗЪ СРБСКІЙ, ПРОГЛАШАВАМО И ОБЯВЛЮЄМО СВИМА И СВАКОМЕ, ДА Є ДРЖАВНЫЙ СОВЕТЬ РЕШИО И ДА СМО МЫ ОДОБРИЛИ И ОДОБРАВАМО; МИХАИЛЪ М. ОБРЕНОВИЋЪ ІІІ. ПО МИЛОСТИ бОЖіОЙ И воЛЬИ Народа КНЯЗЪ СРБСКІЙ, ПО ДОГОВОРУ СА ДРЖАВНИМЪ САВЕТОМЪ РЕШИЛИ СМО И РЕШАВАМО 1.3.

9 И у повељама су аренга и завршни делови по правилу писани вишим стилом, српскословенским језиком, а диспозиција народним језиком (ИВИЋ 1990: 84; ПОЛОМАЦ 2016: 457-458).

${ }^{10} \mathrm{У}$ основи исто запажање изнето је и у другим описима језика административно-дидактичких списа из предвуковског периода, нпр. у ЋОРИЋ 2009: 164; ЈОВАНОВИЋ 2016: 217, као и у описима језика публицистике с краја ХІХ века (ЈОВИЋ 2012а: 292; СТЕФАНОВ 2012: 460).
} 
у то време (ЈОВАНОВИЋ 2016: 216). Међутим, Зборник из 1868. године штампан је у години преломној за коначно званично прихватање Вукових ортографских начела, што се одразило и на његову графију. Као што је познато, 1868. године скинута је последња званична забрана употребе Вукове ћирилице у Србији. Предлог за укидање последње забране употребе Вукове графије у канцеларијама и основним школама достављен је 28. 2. 1868. године (ЛУКОВИЋ 1994: 56-57). Ипак, у уредбама писаним између 28. марта и 20. јуна 1868. године смењују се предвуковска и Вукова графија, ${ }^{11}$ а почев од 17. јула текстови у овом Зборнику штампани су искључиво Вуковом ћирилицом. У језику аката штампаних различитим типом графије постоје и извесне језичке разлике, што ће бити показано у даљој анализи.

3.1. Графијски систем Зборника из 1867. и делова Зборника из 1868. писаних предвуковском, славеносрпском ћирилицом састоји се од следећих графема: $a, \sigma,, 2, \partial, \hbar, e, \varkappa, ~ з, u, \tilde{u}, i, \kappa, л, \mu, \mu, o, n, p, c, m, \hbar, y, \phi, x, u, u, u$, $u, b, b l, b, \mathrm{k}, \epsilon, ю, я\left(\right.$ ЂОРЂИЋ 1990: 217). ${ }^{12}$

3.1.1. Вокал $u$ обележава се осим графијом $u$ (што је најчешће и неће бити посебно документовано), такође и графијама $i, b l$.

3.1.1.1. Графија $i$ пише се:

а) испред прејотованих вокала који означавају групе ja,je, jy: $y$ воєнимъ матеріялима 1.с, меаниія 1.40; где ніє 1.1, министерь финансіє 1.3, 46, uтаціє $1.10,23$, линіє 1.12 , доцніє 1.23 ; у ону штацію 1.16 ;

б) испред графије $u$ у гласовној вредности јu: y државной штампаріи (насловна), у Србіи (насловна), 1.3, 21, штаціи 1.11, према киріи 1.33;

в) испред вокала о: касаџіона власть 1.2 , поступіо $1.40 .^{13}$

3.1.1.1.1. Комбинације слова $і и ̆$ и ый означавају дуго $u$ :

а) у Нјд. одређеног придевског вида м. рода: телеграфскій персональ 1.11, у приход телеграфскій 1.17, већій 1.35, Другій 1.40, свакій 1.41, Дукать новый турскій 1.46, цельй, небушенъ 1.46;

б) у Гмн. именица: двадесетъ речій 1.21, десеть речій 1.21.

\footnotetext{
${ }^{11}$ Вуковом графијом штампане су уредбе од 28. марта, 8. априла (осим делова преамбуле), 24. априла, 7. маја (две уредбе), 25. маја, Прокламација народу српском од 29. маја, два акта привременог намесништва од 29. маја, три од 30. маја, један акт од 31. маја, Прокламација народу српском од 3. јуна. Предвуковском ћирилицом издате су уредбе од 4. априла, 24. априла, две уредбе привременог намесништва од 30. маја, уредба од 31. маја и Прокламација народу српском од 20. јуна.

${ }^{12}$ Овај графијски систем има 36 слова и врло је стабилан. Он се употребљавао после Мркаљеве реформе и у њему је й [j], i [i, j], ы [i], $\epsilon$ [je], ю [ju, ’u], я [ja, 'a], t [e, je, ’e] (МИЛАНОВИЋ 2004: 101). Графије $\hbar, ~ и$ из Вукове реформисане азбуке, уз старо слово $\hbar$, почели су употребљавати и Вукови противници убрзо након 1818. године (ЂОРЂИТ 1990: 200; ИВИТ 1998: 195).

${ }^{13}$ У овом случају графија $i$ може означавати и сонант $j$. В. писање групе јо у даљем тексту.
} 
3.1.1.2. Графија $b$ долази обично на етимолошком месту:

a) у облику Нмн. личне заменице 1. лица: да смо мы одобрили 1.1, 27, 29, 31, 33, 37, 43, поред: да смо ми одобрили 1.40, 2.1, 2;

б) у облицима глагола бити: где неби было 1.5 , было то стално 1.12 , штоо небы противно было 1.5, небы подпунъ быо 1.35, быти 1.35;

в) у наставцима заменичко-придевске промене: државный советь 1.1, правый пошилятель 1.21, талиръ иельй 1.46, талиръ новый 1.47; служителя и осталы потреба дати. 1.11, у уговорима заключенымъ са дотичнымъ државама 1.24, у овымъ радняма 1.24, такса депешны 1.24.

3.1.2. Вокално $p$ бележи се без јора: СРБСКІЙ 1.1, 2, 3, 4 итд. на почетку закона и уредаба, усавршень 1.12, изврше 1.26, на мртве еспапе 1.36 , трговии 1.36, подвргавати 1.39, Првомъ 1.41, првый 1.41, четвртина 1.44 , државнимъ 1.46, сребрне 1.46, извршуюћа 2.1 и сл. ${ }^{14}$

3.1.3. Сонант $j$ бележи се графијама $\check{u}, i$ и двогласним словима $я, \epsilon$, ю у оквиру гласовних група $j e, j e, j y$.

3.1.3.1. Графија $\check{u}$ пише се на крају речи: о новчаной тарифи 1.c, $y$ коіой другой страной држави 1.29; иза вокала у средини речи: о устр. войске 1.c, у чаршійскомъ течаю $1 . c$, у войсии 1.29 , куйну 1.40 , полицайне власти 1.40, коіой 1.46; као и да означи дуги вокал код облика одређеног придевског вида м. рода у Нјд. и код неких именица у Гмн. (в. 3.1.1.1.1).

3.1.3.2. Двогласна слова $я, \epsilon$, ю јављају се на почетку речи и иза вокала: да му се... яви 1.20, явнимъ 1.46, яко избушене 1.47; до края 1.c, Мая 1.с, Юния 1.c, брояти 1.22, коя 1.23, копія 1.24; шта є 1.с, єзику 1.14, єръ 1.23, ни єдне $1.41 ;$ в воєнимъ матеріялима 1.с, где ниє 1.с, стоєћимъ болницама 1.c, препоручуємо 1.1, своє 1.22, трає 1.41, додає се 1.41; Юния 1.с; свою 1.22 , поступаю 1.42 , кою є 1.46 , течаю 1.46 .

3.1.3.3. Група јо бележи се графијама io: ioште 1.21, іошть 2.36; коіой $1.23,29$, коіой 1.46 и сл.

3.1.3.4. О писању групе $и$ било је речи у претходном тексту (в. 3.1.1.1).

3.1.4. Гласови $љ$ и $ъ$ не бележе се посебним графијама већ комбина-

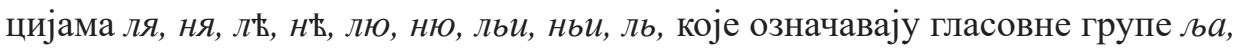
$њ а$, ље, ње, љу, њу, љи, њи, љь о вакупскимъ земяма 1.с, одправлянь 1.22, Другій оделякъ 1.40, одъ 5 рубаля 1.46; у Княжеству, насл., последня 1.2, радня 1.41, упражнява 1.41, крняве 1.47; злоупотребльня 1.с, изъ земль 1.3, определьня 1.22, житель 1.39; Решень 1.с, $н$ ћговомъ 1.2, 28, по $н$ Łмy 1.2,

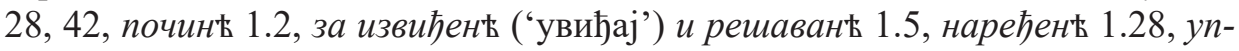

$\overline{14}$ У примеру свръ 1.46, иза вокалног $р$ на крају речи бележи се јор. 
ражнявань 1.41 , раднь 1.41; ${ }^{15}$ пошилятелю 1.22, 23, заключенымъ 1.24; о наплаћиваню виза 1.c, о решаваню 1.c, 1.4, по... траженю 1.23, заменюю се 1.39, изменює се 1.41, радню 1.41; по вольи народа 1.1, 39, на дальину 1.21; унутрашньи дела 1.1, 22, 41, маньи 1.33, примань ньіово 1.45; председатель 1.7, пошилятель 1.13, 23, Надлежательство 1.22, правительственимь 1.36, Првомь одельку 1.41, земальскимъ 2.35, непоколебльиво 2.35.

3.1.5. Графије $\hbar, \hbar, ~ и$ не мешају се у писању: о наплаћиваню виза 1.с, за образовань судеће и касираюће комисіє 1.9, плаћене службене депеше 1.20; одъ извозне ђумручине еспапа 1.с, ослободити одъ извозне ђумручине 1.3, грађ. поступка судскоъ г 1.с, закона о устр. Ђумрука 1.с, недође 1.22, наређено 1.44, међу 1.46; у буиету 1.11, кантариія 1.27, меаниія 1.40 , мецидія 1.46 .

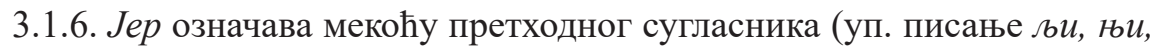
љ). Безгласно је на крају речи код именица IV Стевановићеве врсте: советь 1.1, власть 1.2, 1.5, дужность 1.4, речь 1.14, важность 1.36, казнь 1.38.

3.1.7. Jop је безгласно и пише се на крају речи иза сугласника: зборникъ, законъ, месецъ, данъ, поступка судскогъ, на путнимъ исправама, одъ страни поданика 1.с, Михаиль М. Обреновићъ 1.1, пакъ 1.2, збогъ 1.22, нашемъ 1.30, оделякъ 1.40, казнителногъ законика 1.40, съ правомъ 1.41 итд.

3.2. Правопис је морфофонолошки, како у актима штампаним предвуковском ћирилицом, тако и у онима штампаним Вуковом графијом (део 3борника из 1868. после 17. јула) и карактерише га небележење гласовних промена и састављено писање речи које чине акценатске целине. Ове црте биле су одлика правописа славеносрпског периода (МИЛАНОВИЋ 2004: 96-98).

3.2.1. Гласовне промене - попут једначења сугласника по звучности и по месту творбе и губљења сугласника у сугласничким групама - нису бележене на морфемским границама префикса и коренске морфеме, коренске морфеме и суфикса:

СРБСКІЙ 1.1, обтуженъ 1.6, обтуженомъ 1.6, обштина 1.28, обштељубљеног Кюаза 2.20; относећима се 1.7, подпуно 1.8, 1.11, одправльна 1.11, подпунь 1.13, 35, подписао 1.22, одправляню 1.24, одплатомь 1.33, одпочне 1.41 , надписа 1.47; ${ }^{16}$ србске 1.39 , Приметба 1.47, у другой примьтби 2.2; безплатно 1.22, поред: исплатомь 1.33, исплате $1.46 ;{ }^{17}$

\footnotetext{
${ }^{15}$ Према запажањима В. Јовановића (2016: 218), у војним списима у XIX веку, графија t ce најпре често писала на етимолошком месту, а касније претежно иза $\pi$ и $н$ да означи њихову мекоћу, тј. да заједно са њима означи групе љье и юе, као што је то и овде случај.

${ }^{16}$ У том смислу остаје непромењено и писање групе дс: председникъ 1.6.

17 Чини се да овакви примери одражавају традицију доследнијег обележавања гласовне
} 
изследованњ 1.7, разсматра 1.8, неуместно 1.23, местно меанско право 1.41, наместника 2.20, наместничество 2.22; обдржавати 2.20; нуждна была 1.41, поред: при агенціи букурешкой 2.5, порески 2.5.

3.2.2. Састављено се пишу речи које чине акценатске целине у следећим случајевима:

а) одрична речца пише се састављено без обзира на то уз коју врсту речи долази - глагол, придев или прилог: непрелази 1.6, немогу 1.14, 22, невраћа 1.21, неможе 1.22, недође 1.22, неремети се 1.31, небы 1.41, недонесе 2.21; незадовольна страна 1.6; непосредно 1.7;

б) упитна речца ли пише се састављено са претходном речју: Сли 1.8, Нађели 1.8; поред: є ли 1.20.

3.2.2.1. Енклитички облици помоћног глагола хтети пишу се по правилу одвојено од главног глагола: одређива ће 1.6, доставля ће 1.7, извиђава ће и решавати 1.5, реши ће 1.8, прописа ће 1.9, 26, казни ће се 1.40; мада се среће и: моћиће 1.12; приложиће се 1.21, враћаће 1.24, наплаћиваће се 1.24.

4. Приликом разматрања фонетских особина овог споменика треба раздвојити српске народне општештокавске одлике, које доминирају, од ретких књишких, славеносрпских црта и шумадијско-војвођанских дијалекатских одлика.

4.1. Књишке, рускословенске фонетске црте, везане су за титуле (књаз, министер, полковник), терминологију (Совет, намесничество; точка, казан) и одређену лексику (полза, ползовати се, цел, точно). ${ }^{18}$ Јављају се у тексту оба Зборника и могу да се комбинују са српским народним и српскословенским језичким особинама (благодејање, непунољетан, саотечественик, притежање и сл.), као што је било обично у славеносрпској епохи (МЛАДЕНОВИЋ 1989: 136).

4.1.1. Рускословенски и руски рефлекс полугласника задњег реда (МЛАДЕНОВИЋ 1989: 32) долази у речима: точка, точно, совет, чак и након преласка на Вукову графију, мада се јављају и посрбљени ликови тачка, савет:

точка [параграфа] 1.1, последня точка 1.2, да се точки 1-вой закона 1.35, У точкама подъ бр. 1.37, према точки 2.27; точно наплаћивати 1.11, са точнымъ означен $\mathbf{\mathrm { k }}$ 1.17; државный советь 1.1, са државнимь советомъ 1.39, совета 1.42, Председатель министерскогъ совета 2.1, али и: по

промене код префикса на -з- у српској писмености, о којој говори В. Јерковић (2004: 75).

${ }^{18}$ До истих запажања дошло се проучавањем језика војних текстова из ХІХ века (ЈОВАНОВИЋ 2016: 219). 
договору са државнимъ саветомъ 1.3, 35;

после првог одељка точке $7 \S 2.13$, да се точки под 2. закона 2.31; државни совет 2.19, 21, 31, са државним советом 2.30, 42, поред: државни савет 2.9, тачка 38. указа 2.15.

4.1.2. Рускословенски и руски рефлекс полугласника предњег реда (МЛАДЕНОВИЋ 1989: 32) среће се у терминима: министер, министерство (који долазе и посрбљени), намесничество, и у општијој лексици у тексту Прокламачије, после убиства кнеза Михаила, ради постизања узвишенијег тона: прељубезни, отечество, саотечественик, член:

министеръ 1.1, Министерскогъ совета 1.42 (редовно у потписима уз печат на крају законског акта), али и у тексту закона: министеръ унутрашньи дела 1.11, 35, министерь финансіс 1.36, 46, при министерству 2.5, 10, поред: министарь 2.3, $4,{ }^{19} 7$;

прељубезног владаоца 2.20, саотечественика 2.20, над намим отечеством 2.21, наместничество 2.22, министер правде член овог наместничества 2.22, министер војени 2.45, поред: министар 2.9.

4.1.3. Рускословенски и руски рефлекс назала предњег реда (МЛАДЕНОВИЋ 1989: 33) редовно долази у титули књаз, па и књажевски, књажев, затим у термину част и у апстрактној именици учашће у тексту Прокламащије:

князъ србскій (у преамбули законских одредби) 1.1, 1.2, 1.10, указомъ княжевскимъ 1.10 итд.; старешина оне части войске 1.5;

къаз србски $2.9,{ }^{20}$ о имању књажевом 2.61; Началникъ 2.6, при... учаwћу многобројног народа 2.33.

4.1.4. Рускословенска и руска вредност јата (МЛАДЕНОВИЋ 1989: 24) појављује се у текстовима штампаним Вуковом графијом, нарочито у прокламацијама после убиства кнеза Михаила:

непунољетан 2.19, добро мјеније 2.21, достојни посљедоватељи његове велике мисли 2.33, дјело се његово 2.60, Тутори малољетног књаза 2.61.

4.1.5. Рефлекс вокалног л у духу рускословенског и руског језика долази у титули полковникъ 1.30, 32; иначе је српски народни: Дукатъ... пуноважећій 1.43, дужан 2.16 и сл.

4.1.6. Изостанак новог јотовања у облицима именица заседаније, званије, известије, користољубије, мњеније, полгодије итд. (примере в. у тачки 6.1.1) представља рускословенску, руску и српскословенску особину.

4.1.7. Рускословенско и руско читање група ле, л (МЛАДЕНОВИЋ 1989: 35-36) среће се у примерима: да у споразумлењу са Намесничеством

\footnotetext{
${ }^{19}$ На истој страни, међу потписима, и министеръ.

${ }^{20}$ У уредби од 24. априла, иначе штампаној Вуковом графијом (2.15). реч КНЯЗ остаје написана на овај начин.
} 
2.61; казнителногъ законика 1.40, Намесничество види с утешителним удовољством 2.33, да одбранителну снагу народну 2.36.

4.1.8. Уочена је и рускословенска и славеносрпска лексика (казн, набљудавање, полза, ползовати, призрење, притежање, цуел), која ће и у наредних неколико деценија опстајати у српском стандарду у све ограниченијим сферама употребе (ЈОВИЋ 2011: 84; СТЕФАНОВ 2012: 465): друга казнь 1.38, Ову меру казни 1.38; набљудавања чистоће и здравља 2.15; неможе се овим благодејањем закона ползовати 2.41, у ползу 1.20, ползуюћи се 2.3, на ползу отачбине 2.35; безъ призреня 1.21 ; у његовом притежању 2.16; да немогу свою иель постићи $1.22 .^{21}$

4.2. Особине српског народног језика, које иначе доминирају у тексту Закона и уредба, неће бити детаљно описиване. Овде ће бити скренута пажња на дијалекатске црте присутне у шумадијско-војвођанском, али и у другим народним говорима српског језика, с једне стране, и на специфичне шумадијско-војвођанске језичке одлике, с друге стране, које се јављају у језику Зборника, при чему неких нема у савременом српском стандарду.

4.2.1. У црте шире присутне у дијалектима српског језика, па и у шумадијско-војвођанском дијалекту спадају:

а) екавска замена јата: старешине 1.7, председатель 1.7, председникъ 1.6, према потреби и важности места 1.11, увекъ 1.12 итд.;

б) прелажење финалног -л у -о: ставіо 1.1, 37, предао 1.23, было 1.35, затражіо 1.41, добіо 1.41 и сл.;

в) нестабилност сугласника $x^{22}$ и то:

- у речима домаћег порекла, као и у раније одомаћеним турцизмима: одма 1.14, 15, 18, 41, 2.11, Кадь пошилятель оће 1.16, у коє оће место 1.17-18, оће ли се коме... накнадити 1.24, на већемь одъ сто фати удаленю 1.40, у истый ма 2.35, Заданути НҺговомь великомъ мисли 2.35; у уредби о меанама 1.40, да меане имаю куйну 1.40, аръ ${ }^{23}$ и друге потребне зграде 1.40; што важи и за документе штампане Вуковом графијом: одма 2.16; платити накнадно арач 2.31;

поред ретких примера са $x$ у овој категорији: хтео одговорити 1.17 ,

${ }^{21}$ Неке од ових лексема или лексеме од истих основа, нпр. благодјејаније/благодејаније, дјело/дело, тьбезан, мюеније/мненије, наблудавати, началство, отечество, пользалолза, пользвати се/ ползовати се, част 'део', постедујушчи/последујушти, притјажатељь и сл., пописане су у огледној свесци Речника славеносрпског језика (2017).

${ }^{22}$ Познато је да се у XVIII веку $x$ губило у већини штокавских српских говора (ИВИЋ 2001: 89) и да га Вук није писао у домаћим речима до 1836. године (ИВИЋ 1986: 185), али га после тога уводи у писање. Међутим, ово правило није увек поштовано, што је показала и анализа језика новина с краја ХІХ века (ЈОВИЋ 2012а: 289-290; СТЕФАНОВ 2012: 462-463). Утолико мање чуди нестабилност у писању $x$ тридесетак година пре тога.

${ }^{23}$ ŠKALJIĆ 1989: ahar (aar, ar, jar) m (pers.) 1. štala, konjušnica; 2. gostinjska soba. 
захтевати 1.21, захтевань 1.21;

- у Гмн. заменичко-придевске промене (ИВИЋ, БОШњАКОВИЋ и др. 1994: 340): унутрашньи дела 1.1, 2.1, одъ страни поданика 1.с, одъ дотични раденика или майстора 1.4, одъ... надзорни старешина 1.4, устройства окружни судова 1.2, одъ сировина земальски 1.3, где неби было нарочити стручни командира 1.5, произилазе изъ ти спорова 1.5, о оправкама и израдама исти 1.9, министрима воєни и унутрашньи дела и правде 1.9, по 15 пара порески 1.36, приватны лииза 1.44, поєдины монета 1.45, по 5400 гроша порески 2.5 итд.;

међутим, у актима штампаним Вуковом графијом $x$ се у овој категорији некада пише: министар унутрашњих дела 2.9, 17, 18, 19, Министар просвете и ирквених дела 2.9, 18, Министар иностраних дела 2.9, Наши министри правде и унутрашњих дела 2.40, али не увек: свију наши саотечественика 2.20, на основу земаљски закона 2.20;

- у промени заменица: оделеня ньиова 1.5, приманъ ньіово 1.45, ій (их) 1.39 итд.;

поред $u x$ 2.16, али и коме од њи 2.45, у актима штампаним Вуковом графијом; ${ }^{24}$

г) нестабилност сугласника $ф$, која се огледа у његовој замени другим гласовима (ИВИЋ 1991: 80): о вакупскимъ земляма 1.33, вакупске одношає 1.33, вакупско добро 1.33,

с тим што се он чува у новијим позајмљеницама: Законъ о телеграфу 1.10, штаиіє телеграфске 1.10, штафетомь 1.18, официри 1.29, финансіє 1.36, 38, кафеиія 1.41, франиускій 1.43, По... трифи 1.44, управи фондова 2.1 ;

д) дисимилација у сугласничкој групи мн (ИВИЋ 1991: 154; ИВИЋ, БОШЊАКОВИТ и др. 1994: 370): млогобројног народа 2.33, тавнује 2.55.

4.2.2. Специфичне шумадијско-војвођанске фонетске одлике огледају се у икавизама шумадијско-војвођанског типа (ИВИЋ 2001: 94):

старіи 1.6, найстаріи 1.6, ніє 1.6, 1.47, на депеши 1.16 и сл.; ${ }^{25}$ гди $1.6,{ }^{26}$ поред: где $1.4,5,18,46$; желіо 1.20, Видіо 1.1 (редовно у потписима

\footnotetext{
${ }^{24}$ У основи речи $x$ се чува у несловенским речима и у славенизмима: одъ 5 драхмій 1.44; сходно закону 1.8, 44, кадъ за сходно нађе 1.12, у приходъ 1.17, изб прихода 1.23, 24. Сличну ситуацију у вези са писањем сугласника $x$ примећује и Б. Ћорић (2009: 158): оно одсуствује у домаћим речима, а има га у славенизмима и несловенским речима.

${ }^{25}$ Ови икавизми карактеристика су српског књижевног језика и у XIX веку (ИВИЋ 2001: 92), као и данас.

${ }^{26}$ Облик (2)ди је у широкој употреби у шумадијско-војвођанским и смедеревско-вршачким говорима, а има га и у косовско-ресавским (РЕМЕТИТ 1985:106). То је обичан облик у српском књижевном језику до средине XIX века и у време коначне победе вуковског правца, који се користио поред екавког облика где, као и икавизми желила, живити, поред желела, живети (ИВИЋ 1998: 237).
} 
закона и уредаба из оба годишта), такође и у актима штампаним Вуковом графијом: Видио 2.9, седио 2.55.

4.2.3. У одлику ових докумената, као и других из тог периода, ${ }^{27}$ спада колебање у фонетском лику речи страног порекла, некад чак на истој страни: Декембра 1.35, 38, 39, 2.64, у месеиу Декембру 2.61 и Деиембра 1.37, 39, 42; финансіє 1.36, 38, 45, 47, 2.2, 15, финансије 2.43 и финанціє 1.28, 2.2, 4, финаниије 2.18, 43; фармасиє 2.10; Октомбра 1.25 и Октобра 1.36, 2.12, 22.

5. Морфолошке особине језика Зборника закона и уредба из 1867. и 1868. готово у потпуности одговарају особинама савременог српског језика. ${ }^{28}$ Ситнија одступања тичу се малобројних потврда неких књишких црта и војвођанских дијалектизама.

5.1. У ДИЛмн. именица м. и с. рода доминира наставак -има: Препоручуємо... министрима 1.1, 2, 9, о доказима 1.6, о свимъ приходима и расходима 1.11, по прописанымъ правилима 1.12, паквыль писменима и знацима 1.13-14, Пошилятельима 1.15, са остальмь писмима 1.20 итд.;

али се у следећим случајевима јавља и наставак -ама: заєдно са свима актама 1.7, осталимь актама 2.11, на званичним актама 2.26; на вакупскимъ добрама 1.33, што је одлика језика и других списа с половине XIX века. $^{29}$

5.2. Облици заменичко-придевске промене чешће него данас долазе са покретним вокалима: ${ }^{30}$ до края овога параграфа 1.2, чуваръ државнога печата 1.2, заєдно са свима актама 1.7, О свима приходима и расходима штаціє као и о примльноме и потрошеномъ матеріялу 1.11, на свима пограничнимъ Ђумруцима лежећима край Саве 1.36, на свима явнимь касама 1.44, али и: чуваръ државногъ печата 1.2, кои ће решень првогъ оногъ старешине 1.7, починюћи одъ наймлађегъ 1.6.

\footnotetext{
${ }^{27}$ Б. Ћорић примећује „необичан гласовни и графички лик” имена знаменитих људи у односу на савремено стање (2009: 163). У језику Српских новина и Нишког трговинског гласника из 1895. године забележене су речи страног порекла чији фонетски лик више одговара језику изворнику него данас (ЈОВИЋ 2012а: 290).

${ }^{28}$ Исто је примећено у вези са језиком војних (ЈОВАНОВИЋ 2016: 219) и правних списа из ХІХ века (ЋОРИЋ 2009: 158-159).

${ }^{29} \mathrm{У}$ војним правилима има именица м. и с. рода са наставком -ама у ДИЛмн. (ЈОВАНОВИЋ 2016: 218), док је у уџбеницима права Д. Матића ово једини наставак у тим падежима (ЋОРИЋ 2009: 158).

${ }^{30}$ У Вуковој Писменици (КАРАЏИТ 1814: 33) у Дмн. наведени су само облици на -има. У савременом српском језику (СТЕВАНОВИЋ 1986: 258-259) не инсистира се на одређеној употреби наставка са покретним вокалом.
} 
5.3. Ликови заменица таков/оваков доминирају у односу на какав/maкав/ онакав, а присутни су и ликови каки/таки/оваки/онаки, који су сви одлика Вуковог језика (ИВИЋ 1957: 119; ДАНИЧИЋ 1850: 35): за овакове сnорове 1.7, и такове у одређено време 1.12, такова депеша 1.15, 18, за овакову депешу 1.20, Овакове накнаде 1.23, При траженю оваковы накнада 1.23, о поднаманю оваковы рачуна 1.26, такова... меана 1.41 , делови ньини у таковомъ виду $1.44 ;$ m. є. такве 1.13 , написанъ таквымъ писменима 1.13-14; о овакимъ штетама 1.5, ваља таку одлуку да поднесу 2.48.

5.4. Облик 3. л. мн. презента само у једном случају долази са наставком -ду, што је иначе одлика војвођанских говора (ИВИЋ, БОШЬАКОВИЋ и др. 1997:163-167): нити смеду речи быти $1.14 .{ }^{31}$

6. Од специфичности на нивоу творбе треба издвојити велики број именица са суфиксима -ње и -тељ, као и глаголе са инфиксом -ава-.

6.1. Суфикс -ъе чест је код глаголских именица присутних у различитим терминологијама (ЈОВАНОВИЋ 2016: 221, 227;32 ЛУКОВИЋ 1994: 91), неретко насталих посрбљавањем позајмљеница из рускословенског или руског језика са наставком -ије: где ніє случай злоупотребленя $1.4,31$, изъ... небреженя 1.4, за извиђенъ ('увиђај') и решавань 1.5, дају своја мненя 1.6, изследованъ ('ислеђивање') 1.7, жалбена побућеня ('жалбене побуде') 1.8, о чуваню, надзираваню и рукованю са воєнимъ матеріялима 1.9, Штаціє телеграфске државна су заведеня 1.10, усавршен леня, коя министеръ унутрашньи дела прописивао буде 1.13, Депеше у односу на поступан $\mathbf{~ с ъ ~ н ь и м а ~ 1 . 1 3 , ~ о д п р а в л я н ~} \mathbf{1} 1.13$, одостоверен $\mathbf{\$} 1.15$, са точнымъ означен $\mathrm{k} и ъ$ 1.17, съ назначен $\mathbf{k}$ в 1.20, писмено захтеван безъ призреня 1.21, Из призрења 2.23, неподлеже таксираню 1.22, изображе-

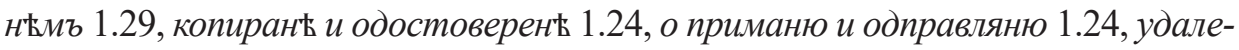
ню 1.40 (удаљење, 'удаљеност'), одъ прилльногъ дозволеня за тражень накнаде 2.3, правила о смотрењу доброте меса и набљудавања чистоће и здравља 2.15, за ствар, каја [sic] се нашла у његовом притежању 2.16, па би се време затруднења подударало са временом одводења ('отмице') или силовања 2.18, због преступьења 2.19, од дана настањења 2.31 .

6.1.1. Рускословенски, руски и, уопште, црквенословенски суфикс-ије редак је у анализираној грађи. ${ }^{33}$ Долази у терминима: заседаније, званије,

\footnotetext{
${ }^{31}$ Мали број потврда ове народне језичке особине присутан је и у језику уџбеника права (ЋОРИЋ 2009: 159, познаду, да знаду, даду).

32 У војним текстовима јавља се паралелна употреба глаголских именица на -ије и -юе.

33 у језику правних уџбеника Б. Ћорић запажа „велики број глаголских именица с
} 
известије, користољубије, мњеније: кадъ раде у засъданію 2.12, уредно у заседания долазити 2.11, по званію 1.6, два званія секретара III. класе 2.5, два званія писара I. класе 2.5, известіє 2.11, учинънимъ изъ користолюбія 1.37, мнъниє 2.10, полгодије 2.31.

6.2. Суфикс -тељ, који означава вршиоца радње, појављује се у терминима, данас, у неким случајевима, обичнијим са суфиксом -лац: рачунополагателя 1.4 и рачунополагатеља 2.9, рукователя 1.4 , узрокователь штете 1.5, председатель 1.7, 39, 2.1, ${ }^{34}$ служителя 1.11, 23, пошилятель 1.13, 21, Ако... жалителю даде право на тражень накнаде 2.3, рачуноводителя 2.5, деловодителя у одбору 2.11, бранитеља 2.19, тужитељ 2.19 (уп. ЈОВИһ 2011a: 395). ${ }^{35}$

6.3. Инфикс -ава- још увек је чест код глагола, што је карактеристика и других текстова (ЋОРИЋ 2009: 159): оснажаваю или уништаваю 1.2, оснажава решень 1.8, извиђаваю и решаваю 1.4, извиђава ће и решавати 1.5 , о ... надзираваню и рукованю 1.9, штаціє телеграфске установлявати 1.10, назначаваће се 1.11, определяваће самь 1.11, о примањю и одпуштаваню служителя 1.12, власти... подчиняваю 1.39, ослобођаваю 1.39, 2.31, настоявати 2.35 .

7. Неке синтаксичке црте Зборника закона и уредба из 1867. и 1868. године, будући разматране у поменутој монографији М. Луковића (1994) о развоју српског правног стила, биће документоване ради поређења са стањем у језику уџбеника права (ЋОРИЋ 2009) и војних приручника (ЈОВАНОВИЋ 2016). Ради се о атрибутској употреби партиципа, једној од најтипичнијих књишких црта, реду речи у реченици, као и о деперсоналности и номиналности - важним синтаксичко-стилским одликама административног стила (ПОЛОМАЦ 2016: 464).

7.1. Атрибутска функција партиципа добро је потврђена у језику $3 a$ кона и уредба, при чему се углавном јављају партиципи на -ћu, а од оних

рускословенским ликом на -ије, али су оне још чешће са домаћим ликом на -ње” (2009: 162).

${ }^{34}$ У уредбама од 7. и 25. маја 1868. употребљено је председник, да би се након атентата на кнеза Михаила у Прокламацији и у актима о формирању привременог намесништва опет вратио термин председатељ $2.21,22,23,24$, односно председател 2.25 , председатель 2.27 , тамо где графија није Вукова. Термини председник 2.46 и подпредседник 2.47 појављују се у Закону о уређењу Народног позоришта у Београду од 17. октобра 1868. године.

${ }^{35}$ И у уџбеницима права Д. Матића честе су именице на -тељ, а ретке конкурентске форме на -лач (ЋОРИТ 2009: 162). 
на -вши, једино благопочивши: ${ }^{36}$ коя се на сировину изъ земль износећу се [sic] наплаћує 1.3, у стоєћой войсии 1.4, за... образовань судеће комисіє 1.5, заєдно са свима актама на предмет относећима се 1.7, судећа комисія 1.8, судећой комисіи 1.8, касираюћа комисія 1.8, платиће и за одговорь припадаюћу таксу 1.20, на свима пограничнимь Ђумруцима лежећима край Саве 1.36, извриуюћа власть 2.1, опредељена закона... односећа се на случаје 2.24, кад се скитајући се ччигани 2.31; која им је блаженопочивиим Кюазем поверена 2.21, жалости за блаженопочившим Кназом 1.26, поводомь убиства блаженопочившегъ княза 2.27.

7.2. Реченица је некада врло дуга (уп. ЛУКОВИЋ 1994: 139), ${ }^{37}$ са уметнутим зависним реченицама, набрајањима и сл.: За све штете у воєнимь матеріялима, коє излазе изъ квареня у изради одъ дотични раденика или майстора, или изъ рђавогъ чуваня или рукованя, слабогъ надзора, и небреженя или неиспуняваня правила одъ дотичногъ рачунополагателя, рукователя, надзорни старешина или наредбодавца, као и за све штете у воєнимь матеріялима учинъне лицемь коє има службу или одређену дужность при войсии, - надлежне су следеће власти да решаваю спорове о накнади. 1.4, Овлашћую се дотични министри, да могу, у колико власти ма коє државе подчиняваю српске житель плаћаню такса за визе на путнимъ исправама, или ій од тога сасвимь ослобођаваю, - и они поданике те државе на свимъ пограничнимь местима подвргавати подобномъ плаћаню или ій сасвимь одъ тога ослобођавати, у смислу узаямности. 1.39.

7.3. Ред речи у реченици одликују архаичне црте попут положаја атрибута иза именице и смештања глагола, често инфинитива, на крај реченице. Ове особине одликују и Вуков језик (ИВИЋ 1957: 122-123), као и језик предвуковских писаца и нису биле напуштене до краја XIX века, што се види из језика новина (ЈОВИЋ 2012: 95).

7.3.1. Место атрибута иза именице представља стару особину (BROZOVIĆ, IVIĆ 1988: 40), присутну и у другим правним списима (ЛУКОВИЋ 1994: 138; ${ }^{38}$ ЋОРИЋ 2009: 161): на предметь относећима се 1.7, Штаціє телеграфске државна су заведеня 1.10, служителя канцеларискій 1.12, депеше службене 1.13, За депешу просту 1.21, двадесеть пара чарииски 1.21, изъ прихода телеграфскогъ 1.23, болница државнь 1.26 и сл.

\footnotetext{
${ }^{36}$ Уп. ЛУКОВИЋ 1994: 131-135, 142-143. Б. Ћорић у језику уџбеника правних наука осим партиципа на - $и$ и -в(uu) запажа и континуанте некадашњег партиципа презента пасива на -м (2009: 159). Употребу партиципа у језику војних текстова из XIX века прати и В. Јовановић (2016: 221).

37 Ово посебно важи за правне текстове са почетка проучаваног периода (шездесете и седамдесете године XIX века), који имају процедурални карактер (ЛУКОВИТ 1994: 85-88).

${ }^{38}$ То је честа особина у правним списима, која временом ипак слаби (исто: 78-79).
} 
7.3.2. Глагол на крају реченице, било инфинитив или лични глаголски облик, такође је особина и Вуковог језика, и језика славеносрпских писаца (ИВИЋ 1957: 123), као и других правних и новинских текстова у другој половини ХІХ века (ЛУКОВИЋ 1994: 82;39 ЋОРИЋ 2009: 160; ${ }^{40}$ ЈОВИЋ 2012: 95): коя се на сировину изъ земль износећу се [sic] наплаћує 1.3, коє се пошилятельима депеша издавале буду 1.23; Прописане таксе телеграфске подпуно и точно наплаћнвати [sic], и приходе у определьно време коме треба предавати 1.11, Но у колико брой више класе небы подпун быо, у толико брой ниже класе може већій быти. 1.35 итд.

7.3.3. Честа употреба инфинитива била је особина књижевних и других текстова у ХІХ веку (ЛУКОВИЋ 1994: 117-121; ЈОВИЋ 2012: 95) и обично се тумачи страним утицајем: кои ће решень првогъ оногъ старешине, према даномь случаю и закону, оснажити или пречначити... 1.7, определяваће самь, колико ће се коіой штаціи званичника, служителя и осталь потреба дати. 1.11, А чимь се такова по плану меана подигне и радити одпочне, одма има престати упражнявати меанску радю онай 1.41 и сл.

7.4. Деперсоналност и номиналност представљају доминантне синтаксичко-стилске одлике административног стила и огледају се, између осталог, у употреби пасива и кроз декомпоновање предиката.

7.4.1. Рефлексивни пасив доминира у односу на партиципски, што је одлика правних списа и у периоду након шездесетих година XIX века (ЛУ КОВИЋ 1994: 135-136): Неће се примити ни телеграфомъ одправяти оне приватне депеше 1.15, Ако бы се коимъ случаємъ наплатило одъ пошилятеля мань таксе него што треба 1.21, да му се телеграфомъ яви 1.20; Депеше знаничне могу быти саставльне на комъ было єзику 1.14, Ако є депеша већъ одтелеграфирана 1.20 и сл.

7.4.2. Уз бројност глаголских именица на -юе, номиналности правних списа доприноси и декомпоновање предиката (ЛУКОВИЋ 1994: 93-94, 139) уз глаголе узимати, извриити, упражњавати, чинити, радити: узима у претресь 1.8, могу извриивати набавке и оправке 1.26, наплате и исплате имаю извршити 1.46, одма има престати упражнявати меанску радню онай 1.41, Чинити наплате и исплате 1.46, кадъ раде у засъданію 2.12 итд.

8. Зборници закона и уредба издати у Кнежевини Србији 1867. и 1868. године писани су у српским стандардним језиком друге половине XIX века,

\footnotetext{
${ }^{39}$ М. Луковић запажа да број оваквих примера у правним текстовима идући ка крају века опада.

${ }^{40}$ Б. Ћорић ову појаву тумачи барокизацијом језика.
} 
у основи шумадијско-војвођанским дијалектом са мањим уделом славеносрпских елемената и дијалектизама, општијештокавских и шумадијсковојвођанских. Зборник из 1867. и део Зборника из 1868. године штампани су предвуковском, славеносрпском ћирилицом, док је део млађег Зборника издат Вуковом графијом, будући да је 1868. скинута и последња забрана њене употребе у канцеларијама и основним школама. Славеносрпски елементи јављају се у фонетици, превасходно у терминологији (књаз, намесничество, началник, совет; званије, полгодије; полза, точка, цел и сл.) и синтакси (употреба партиципа, дуга реченица, често са глаголом на крају и уз појачану употребу инфинитива, положај атрибута иза именице). Општештокавски дијалектизми у виду изостајања сугласника $x$ (у заменичко-придевској промени, у домаћим речима и старијим позајмљеницама) и шумадијсковојвођанских икавизама код глагола VII Белићеве врсте - присутни су и у језику других књига административно-дидактичког карактера са којима је вршено поређење (војни и правни уџбеници с половине XIX века). Деперсоналност и номиналност, као важне одлике административног стила, постижу се у Зборнищима творбом великог броја именица на -ње у функцији термина, употребом пасива (чешће рефлексивног) и декомпоновањем предиката. Са променом графије у Зборнику из 1868. године иду и промене у језику: термини са рускословенским фонетским одликама посрбљавају се (министар, caвет; осим код највише владарске титуле књаз), пише се, додуше ретко, сугласних $x$ у категоријама у којима се раније испуштао. Рускословенски фонетски ликови појављују се у већем броју него иначе у прокламацијама и уредбама писаним после атентата на кнеза Михаила, што одражава схватање да су одлика вишег стила, чиме се могло оправдати њихово коришћење у језику у врло тешком историјском тренутку.

\section{Цитирана литература}

ГРИЦКАТ, Ирена. „Покушаји стварања српске научне терминологије средином прошлог века". Наш језик (Нова серија) књ. XIV, св. 2-3 (1964): стр. 130-140.

ДАНИЧИЋ, Ђуро. Мала српска граматика. Беч: Штампарија Јерменског манастира, 1850.

ЂОРЂИЋ, Петар. Историја српске ћирилице: палеографско-филолошки прилози. - 3. изд. Београд: Завод за уџбенике и наставна средства, 1990.

ИВИЋ, Милка. „Једно поређење Вуковог језика са нашим данашњим књижевним језиком". Зборник Матице српске за лингвистику књ. I (1957): стр. 114-126.

ИВИЋ, Павле. Српски народ и юегов језик. - 2. изд. Београд: Српска књижевна задруга, 1986.

ИВИЋ, Павле. О језику некадашњем и садашњем. Београд-Приштина: БИГЗ-Јединство, 1990. 
ИВИЋ, Павле. Изабрани огледи II, Из историје српскохрватског језика. Ниш: Просвета, 1991.

ИВИЋ, Павле. Преглед историје српског језика, прир. Александар Младеновић, Целокупна дела П. Ивића; т. 8. Сремски Карловци - Нови Сад: Издавачка књижарница Зорана Стојановића, 1998.

ИВИЋ, Павле. Дијалектологија српскохрватског језика: увод и штокавско наречje; прир. Драгољуб Петровић, Целокупна дела П. Ивића; т. 2. Сремски Карловци - Нови Сад: Издавачка књижарница Зорана Стојановића, 2001.

ИВИЋ, Павле и Жарко Бошњаковић, Гордана Драгин. Банатски говори шумадијско-војвођанског дијалекта, Прва књига: увод и фонетизам. Српски дијалектолошки зборник XL, 1994.

ИВИЋ, Павле и Жарко Бошњаковић, Гордана Драгин. Банатски говори шумадијско-војвођанског дијалекта, Друга књига: морфологија, синтакса, закључци, текстови. Српски дијалектолошки зборник XLIII, 1997.

ЈЕРКОВИЋ, Вера. „О транскрипцији српскословенских текстова”. Вера Васић (ур.). Предавања из историје језика, Лингвистичке свеске 4. Нови Сад: Филозофски факултет, 2004, 70-86.

ЈОВАНОВИЋ, Владан. Српска војна лексика и терминологија. Београд: Институт за српски језик САНУ, Монографија 25, 2016.

ЈОВИЋ, Надежда. „О лексичким слојевима у језику Нишког трговинског гласника (8. 10. 1895 - 25. 12. 1895)". Годишњак за српски језик и књижевност, Година XXIV, број 11 (2011): 81-89.

ЈОВИЋ, Надежда. „О лексици Зборника закона и уредба и 1867. године”. Милош Ковачевић (ур.). Кюижевни (стандардни) језик и језик књижевности, Књига 1. Српски језик, књижевност, уметност, Зборник радова са V међународног научног скупа одржаног на Филолошко-уметничком факултету у Крагујевцу (29-30. Х 2010). Крагујевац: Филолошко-уметнички факултет, 2011a, 387-397.

JОВИЋ, Надежда. „О неким синтаксичким одликама језика београдских и нишких новина с краја XIX века". Годишњак за српски језик и књижевност, Година XXV, број 12 (2012): 89-98.

JОВИЋ, Надежда. „О језику београдских и нишких новина с краја XIX века”. Време и история в славянските езиии, литератури и култури, Сборник с доклади от Единадесетите начионални славистични четения, 19-22 април 2012, Том пьрви, Езикознание. София: Софийски университет „Св. Климент Охридски", 2012a, 287-293.

КАРАЏИЋ, Вук Стефановић. Писменица сербскога језика. Виена 1814. Горњи Милановац - Београд: Привредна књига - Универзитетска библиотека „Светозар Марковић”, 1984.

ЛУКОВИЋ, Милош. Развој српског правног стила. Београд: Службени гласник, 1994.

МЛАДЕНОВИЋ, Александар. Славеносрпски језик. Нови Сад - Горњи Милановац: Књижевна заједница Новог Сада - Дечије новине, 1989. 
МИЛАНОВИЋ, Александар. Кратка историја српског књижевног језика. Београд: Завод за уџбенике и наставна средства, 2004.

ПОЛОМАЦ, Владимир. Језик повеља и писама Српске деспотовине. Крагујевац: ФИЛУМ, 2016.

РЕМЕТИЋ, Слободан. Говори ичентралне Шумадије. Српски дијалектолошки зборник XXXI, 1985.

РЕЧНИК СЛАВЕНОСРПСКОГ ЈЕЗИКА, огледна свеска. Прир. Исидора Бјелаковић, Ирена Цветковић Теофиловић и Александар Милановић. Нови Сад: Матица српска, 2017.

СТЕВАНОВИЋ, Михаило. Савремени српскохрватски језик (граматички систем и књижевнојезичка норма), I Увод, фонетика, морфологија. - 5. изд. Београд: Научна књига, 1986.

СТЕФАНОВ, Мартин. „За някои колебания в книжовната норма на сръбския език от края на XIX и началото на XX век в контекста на неговото развитие”. Време и история в славянските езици, литератури и култури, Сборник с доклади от Единадесетите национални славистични четения, 19-22 април 2012, Том първи, Езикознание. София: Софийски университет „Св. Климент Охридски", 2012, 460-466.

ТОШОВИЋ, Бранко. Функциионални стилови. Сарајево: Свјетлост, 1988.

ЋОРИЋ, Божо. Лингвомаргиналије. Београд: Друштво за српски језик и књижевност, 2009.

$* * *$

BROZOVIĆ, Dalibor i Pavle Ivić. Jezik srpskohrvatski/ hrvatskosrpski, hrvatski ili srpski, Izvadak iz II izdanja Enciklopedije Jugoslavije. Zagreb: Jugoslavenski leksikografski zavod „Miroslav Krleža”, 1988.

ŠKALJIĆ, Abdulah. Turcizmi u srspskohrvatskom jeziku. - 6. izd. Sarajevo: Svjetlost, 1989.

\section{Извори}

1. Зборникъ закона и уредба изданы у Княжеству Србіи од почетка до края 1867. године. XX. У Београду, У државной штампаріи 1867.

2. Зборник закона и уредба изданих у Кюжеству Србији од почетка до краја 1868. године. XXI. У Београду, у државној штампарји 1868. 
Nadežda D. Jović

\section{SOME ATTRIBUTES OF LANGUAGE USED IN CODIFICATION OF LAWS AND REGULATIOS RELEASED IN A YEAR 1867 AND 1868}

This paper shows some language attributes (graphic, phonetic, morphological, formation and syntactic) of Codification of laws and regulations released in a year 1867 and 1868 (Zbornik zakona i uredba 1867 and 1868) in order to establish what characterize administrative style of standard language which was used in times correspondents the official victory Vuk Karadzic principles. Language characteristics noted here is compared with ones from older period, vernacular language and finally, with Serbian standard language. It is concluded that the basis of language is Sumadia-Vojvodina dialect, deviation from the modern language is noted as a issuing of consonant $h$, especially in forms of ejective pronominal declension and broader emerging of ikavian substitution of yat. Impact of SlavenoSerbian literature is visible as a putting of adjectives behind of nouns and using of former participles in attribute function.

Keywords: Codification of laws and regulations released in a year 1867 and 1868, language attributes, Sumadia-Vojvodina dialect, Serbian standard language. 